\title{
Effect of age on magnesium deficiency in rats
}

\author{
By B. S. W. SMITH AND A. C. FIELD \\ Moredun Institute, Edinburgh, 9 \\ (Received 27 March 1963-Revised 7 fune 1963)
}

The development of hypomagnesaemia in calves to the stage at which tetanic convulsions occur has been shown experimentally by Blaxter, Rook \& MacDonald (1954) to be a comparatively slow process. In contrast, hypomagnesaemic tetany can develop in the dairy cow and lactating ewe with great rapidity (Rook \& Balch, 1958; L'Estrange \& Axford, I963). The increased speed of the development of the condition in the mature animal may be partly due to its inability to mobilize reserves of magnesium from bone as readily as does the young animal (Wilson, 1960).

It was not possible to carry out a controlled experiment to study the lability of $\mathrm{Mg}$ reserves in the adult bovine owing to the difficulty in providing a $\mathrm{Mg}$-deficient diet that would support rumination, and to the prohibitive cost of slaughtering animals to obtain tissues for analysis. For these reasons we used rats.

There have already been several reports on the effect of $\mathrm{Mg}$ deficiency on the content of $\mathrm{Mg}$ in various tissues in the rat. For example, a marked depletion of the $\mathrm{Mg}$ content of bone in young rats on a $\mathrm{Mg}$-deficient diet has been described by Duckworth, Godden \& Warnock (1940), and MacIntyre \& Davidsson (1958), under similar conditions, were unable to detect any loss of $\mathrm{Mg}$ from soft tissues other than muscle.

In the study to be described here, the effect of maturity on the susceptibility to $\mathrm{Mg}$ deficiency and on the availability of $\mathrm{Mg}$ reserves has been investigated by feeding young and adult rats of the same strain on a $\mathrm{Mg}$-free diet for 18 days. The development of hypomagnesaemia was followed during the course of the experiment and, after slaughter, the depletion of $\mathrm{Mg}$ reserves was determined by analysis of selected tissues. The calcium, sodium and potassium contents of the tissues of adult rats were also studied to see if there were changes associated with $\mathrm{Mg}$ deficiency. In addition, the endogenous $\mathrm{Mg}$ loss of the adult animals on a $\mathrm{Mg}$-free diet was determined.

\section{EXPERIMENTAL}

\section{Animals}

Hooded Lister rats which had been maintained on a stock diet (PRM diet as used by the Ministry of Supply, Allington Farm, Porton Down, Wiltshire) were used. The adult rats were males aged 9-12 months and weighed on average $400 \mathrm{~g}$. The young rats were 8 weeks old and of both sexes, the males weighing approximately $190 \mathrm{~g}$ and the females $140 \mathrm{~g}$. The animals were housed in cages constructed entirely of Pyrex glass and Perspex to the design of C. H. Gallagher, J. D. Judah \& K. R. Rees (I959, personal communication). 


\section{Diet}

The experimental diets were based on the recommendations of Cuthbertson (1957) and were given $a d$ lib. from Perspex troughs. The composition was (parts) cane sugar 660 (castor), casein (low-vitamin content; Genatosan Ltd) 200, arachis oil 100 and mineral mixture 50 (control diet) or 45 ( $\mathrm{Mg}$-deficient diet). The mineral mixture contained (parts): $\mathrm{CaCO}_{3}, 75 \cdot 0 ; \mathrm{KH}_{2} \mathrm{PO}_{4}, 88 \cdot 0 ; \mathrm{NaCl}, 24 \cdot 7 ; \mathrm{Na}_{2} \mathrm{CO}_{3}, 34 \cdot 5 ; \mathrm{FeSO}_{4} \cdot{ }_{7} \mathrm{H}_{2} \mathrm{O}$, I.24; $\mathrm{MnSO}_{4} \cdot 5 \mathrm{H}_{2} \mathrm{O}, 0.405 ; \mathrm{ZnSO}_{4} \cdot 7 \mathrm{H}_{2} \mathrm{O}, 0.089 ; \mathrm{CuCl}_{2} .2 \mathrm{H}_{2} \mathrm{O}, 0.267 ; \mathrm{NaF}, 0.00 \mathrm{I}$; $\mathrm{KI}, 0.00 \mathrm{I}_{3} ; \mathrm{KBr}, 0.0004 ; \mathrm{H}_{2} \mathrm{MoO}_{4}, 0 \cdot 0008$, and only in the control diet $\mathrm{MgSO}_{4} \cdot{ }_{7} \mathrm{H}_{2} \mathrm{O}$, $25^{\circ} 7$.

All constituents of the mineral mixture were AR except manganese sulphate and zinc sulphate which were Specpure quality (Johnson Matthey \& Co. Ltd). No special purification was undertaken.

Fat-soluble vitamins were dissolved in the arachis oil to give $(\mathrm{g} / \mathrm{kg}$ diet): vitamin $\mathrm{A}$ acetate $0.0012, \mathrm{DL}-\alpha$-tocopheryl acetate 0.28 , ergocalciferol 0.00005 . Water-soluble vitamins were given in the drinking water. The quantities (g) dissolved in 4.51 . distilled water were: thiamine $\mathrm{I} \cdot 2$, riboflavin $0 \cdot 4$, calcium pantothenate $4 \cdot 0$, cyanocobalamin 0.002 , nicotinic acid 4.0 , folic acid 0.04 , biotin 0.008 , pyridoxine 0.32 , inositol $9^{\circ} 0$, choline chloride $40^{\circ} 0, p$-aminobenzoic acid $3 \cdot 0$, dicalcium salt of 2 -methylI, 4-naphthohydroquinone diphosphoric acid (Synkavit; Roche Products Ltd) 0.08 , together with chlortetracycline hydrochloride $0 \cdot 16$. To prevent bacterial growth this solution was kept at $-20^{\circ}$, and before use it was thawed and diluted ( $\left.15 \%, v / v\right)$ with distilled water. Sufficient drinking mixture for at least $\mathrm{I}$ week was prepared.

\section{Experimental design}

Adult rats. Forty-eight adult rats were divided randomly into two groups of twenty-four. One group was given the $\mathrm{Mg}$-deficient diet and the other group the control diet. All animals were housed six to a cage except for twelve on the deficient diet. The latter were housed in pairs and, after allowing 2 days for the excretion of $\mathrm{Mg}$ originating from the stock diet, their excreta were collected on tinned trays for five successive periods of 3 days and analysed for $\mathrm{Mg}$. To reduce the quantity of material for ashing, spilt diet uncontaminated with excreta was removed daily from the trays.

Six animals from each group of twenty-four were bled when the Mg-deficient diet was introduced and again after $4,8,1 \mathrm{I}, 14$ and 18 days. The rats were bled in rotation so that no animal was bled for the second time until the fifth bleeding. Blood was removed by cardiac puncture through a $0.8 \times$ I $5 \mathrm{~mm}$ needle into a heparinized syringe by the method described by Burhoe (1940). From each rat $3 \mathrm{ml}$ of whole blood were taken to allow analysis of individual samples. All rats were weighed weekly.

On the I 8th day after the introduction of the deficient diet each rat was given an intraperitoneal injection of ${ }^{22} \mathrm{Mg}$ containing I $\mathrm{mg}$ stable $\mathrm{Mg}$ as carrier. Four rats, two from each dictary group, were killed by decapitation at intervals up to $22 \mathrm{~h}$ after dosing. The following tissues were removed immediately after death: brain, heart, liver, both kidneys, muscle (inner thigh), left femur and the left side of the mandible. 
Apart from the livers, which were analysed individually, tissues from a pair of rats with a common killing time and dietary history were pooled for analysis.

The results for the uptake of ${ }^{28} \mathrm{Mg}$ are described in another paper (Field \& Smith, 1964).

Young rats. Six (two $\delta$ and four 9 ) and twelve (four $\delta$ and eight 9 ) rats were given the control and Mg-deficient diets respectively. Three of the control and six of the deficient animals were bled on the Ist and $5_{5}$ th day of the experiment and the remaining animals on the 8 th day. After 18 days on the diets the rats were bled and killed by decapitation. The kidneys, left femur and the left side of the mandible were removed for analysis.

\section{Analytical procedure}

The heparinized whole blood was centrifuged immediately and the plasma was separated and stored at $-20^{\circ}$ until analysed for $\mathrm{Ca}$ and $\mathrm{Mg}$.

Soft tissues were dried at $60^{\circ}$ to constant weight and ashed in silica beakers for the measurement of $\mathrm{Mg}, \mathrm{Ca}, \mathrm{Na}$ and $\mathrm{K}$.

Bones were dried to constant weight at $100^{\circ}$, ashed in Pyrex glass beakers and their $\mathrm{Mg}$ content was determined.

Combined total faeces and urine from each pair of rats for each 3 -day period were ashed and analysed for $\mathrm{Mg}$.

All samples except plasma were ashed with $5 \mathrm{ml}$ conc. $\mathrm{HNO}_{3}(\mathrm{AR})$ until evolution of brown fumes ceased. This process was repeated until little carbon remained, and the ashing was completed with a mixture of equal volumes of $\mathrm{HClO}_{4}(60 \%, \mathrm{AR})$ and conc. $\mathrm{HNO}_{3}$. Water $(20 \mathrm{ml})$ was added and the mixture boiled and filtered while hot into a volumetric flask.

Ca was determined by the method of Henley \& Saunders (1958).

After removal of $\mathrm{Ca}$ as oxalate, $\mathrm{Mg}$ was precipitated as $\mathrm{MgNH}_{4} \mathrm{PO}_{4}$ from the supernatant solution. The precipitate was centrifuged, washed once with $33 \%(\mathrm{v} / \mathrm{v}) \mathrm{NH}_{4} \mathrm{OH}$ and the $\mathrm{Mg}$ determined in either of two ways. For plasma and bone the $\mathrm{MgNH}_{4} \mathrm{PO}_{4}$ was dissolved in two drops of $50 \%$ (v/v) conc. $\mathrm{HNO}_{3}$ and transferred to a cuvette with about $30 \mathrm{ml}$ water. After addition of $0.5 \mathrm{ml} 2 \%(\mathrm{w} / \mathrm{v}) \mathrm{KCN}, 3 \mathrm{ml} 3 \mathrm{~N}-\mathrm{NH}_{4} \mathrm{OH}$ and $0.2 \mathrm{ml}$ Eriochrome black $\mathrm{T}$ in 2-methoxy ethanol ( $1 \mathrm{mg} / \mathrm{ml}$ ), the mixture was titrated stepwise with standard EDTA solution (1 m-equiv./1.) in a Unicam SP $35^{\circ}$ spectrophotometer at $620 \mathrm{~m} \mu$, the solution being mixed by a stream of air. The end-point was determined from the plot of extinction against volume of titrant.

For the remaining samples the $\mathrm{MgNH}_{4} \mathrm{PO}_{4}$ was dissolved in $\mathrm{HNO}_{3}$ as above and determined in the same manner as $\mathrm{Ca}$ in the method of Henley \& Saunders (1958).

$\mathrm{Na}$ and $\mathrm{K}$ were determined with the EEL (Evans Electroselenium Ltd) flame photometer after suitable dilution of the ashed solution.

\section{RESULTS}

Clinical signs. The first sign of $\mathrm{Mg}$ deficiency was reddening of the ear which took slightly longer to develop in the adult (I I-I4 days) than in the young (8-I I days) rats. Hyperirritability developed in both groups $2-3$ days after the ear reddening. 
Convulsions were seen in four of the young but in none of the adult rats. No attempt was made to induce convulsions.

The weight curves of the groups of rats are shown in Fig. I. The weights of the $\mathrm{Mg}$ deficient adult rats remained almost constant whereas those of the controls increased throughout the experiment. The young rats gained weight on both diets, but much more rapidly on the control than on the deficient diet.

Effect of carrier dose of $\mathrm{Mg}$. The carrier dose of $\mathrm{I} \mathrm{mg} \mathrm{Mg}$ caused no apparent increase in the $\mathrm{Mg}$ concentration in the tissues taken from rats killed at any time after dosing. The time of killing was therefore ignored and the results were pooled for statistical analysis.

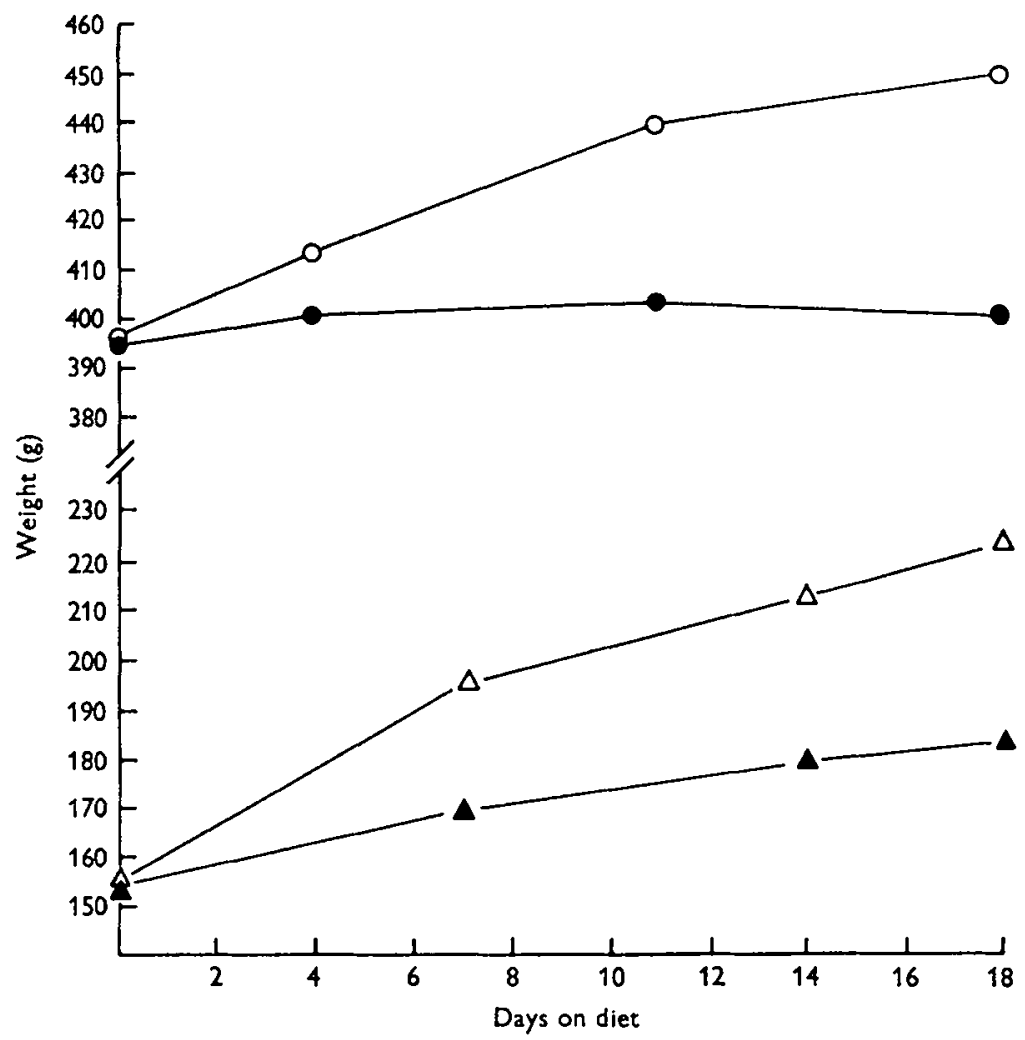

Fig. I. Effect of the control and Mg-free diets given ad lib. on the body-weight of adult and young rats. Mean values for: $\bullet-$, adult rats on the $\mathrm{Mg}$-free diet; $0-0$, control adult rats; $\Delta-\Delta$, young rats on the $\mathrm{Mg}$-free diet; $\Delta-\Delta$, control young rats.

Plasma Mg. 'The mean values found for the concentration of $\mathrm{Mg}$ in plasma of the groups of rats are shown in Fig. 2. The introduction of the $\mathrm{Mg}$-deficient diet resulted in a marked reduction in the plasma $\mathrm{Mg}$ concentration, the mean values for adult and young rats falling to 0.49 and $0.55 \mathrm{mg} / \mathrm{r} 00 \mathrm{ml}$ respectively in 8 days and thereafter remaining constant till the end of the period of observation. No significant change was observed in the mean values for animals on the control diet.

Endogenous $M g$ excretion. The mean values with their standard errors for the total daily excretion of $\mathrm{Mg}$ by the adult rats on the $\mathrm{Mg}$-free diet for the five successive col- 
lection periods were (mg/rat day) $\mathrm{I} \cdot 17 \pm 0.044,0.90 \pm 0.025,0.82 \pm 0.020,0.70 \pm 0.067$ and $0.81 \pm 0.032$ respectively. They fell significantly from the first to the second period $(P<0.01)$ and from the second to the third period $(P<0.05)$, and thereafter remained constant.

Bones. The values obtained for the $\mathrm{Mg}$ content of the femur and mandible are given in Table 2. There was a significant $(P<0.005)$ decrease in the concentration of $\mathrm{Mg}$ in both the mandible and femur of both the young and adult rats given the $\mathrm{Mg}$-deficient diet. The decrease was significantly $(P<0.01)$ greater in the young than in the adult rats. It will be noted that there was a significantly $(P<0.01)$ greater concentration of $\mathrm{Mg}$ in the femur of the young control rats than in that of the adult controls.

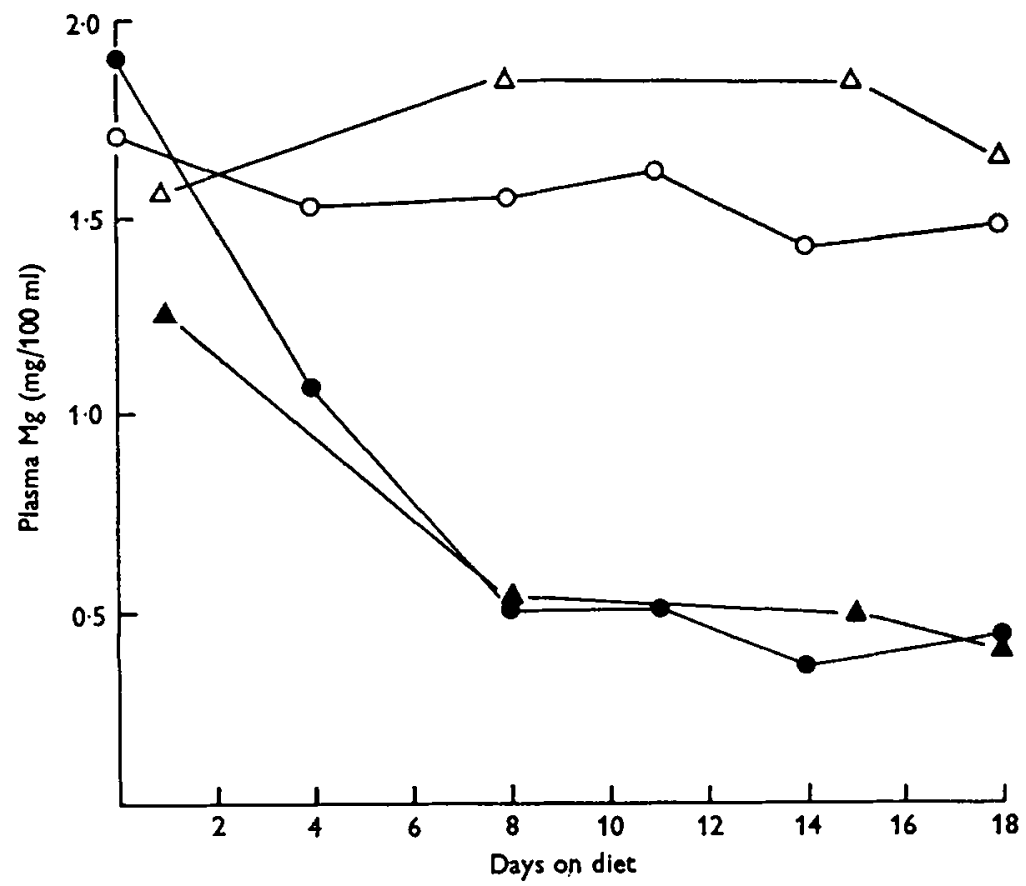

Fig. 2. Effect of the control and $\mathrm{Mg}$-free diets given ad lib. on plasma $\mathrm{Mg}$ concentrations in adult and young rats. Mean values for: $-\longrightarrow$, adult rats on the $\mathrm{Mg}$-free diet; $\bigcirc-0$, control adult rats; $\Delta-\Delta$, young rats on the $\mathrm{Mg}$-free diet; $\Delta-\Delta$, control young rats.

Table I. Mean values with their standard errors for concentration ( $g / 100 \mathrm{~g}$ dry matter) of magnesium in bones of young and adult Mg-deficient and control rats and the degree of depletion in the deficient rats

\begin{tabular}{|c|c|c|c|c|c|c|}
\hline \multirow[b]{2}{*}{ Bone } & \multicolumn{3}{|c|}{ Young rats } & \multicolumn{3}{|c|}{ Adult rats } \\
\hline & Deficient & Control & $\begin{array}{l}\text { Depletion } \\
(\%)\end{array}$ & Deficient & Control & $\begin{array}{c}\text { Depletion } \\
(\%)\end{array}$ \\
\hline Femur & $0.38 \pm 0.014$ & $\begin{array}{c}0.52 \pm 0.014 \\
\text { (II) }\end{array}$ & $28 \cdot 2$ & $\begin{array}{c}0.38 \pm 0.0080 \\
\text { (12) }\end{array}$ & $\frac{0.42 \pm 0.0060}{(12)}$ & $9 \cdot 5$ \\
\hline Mandible & $\begin{array}{c}0.49 \pm 0.0074 \\
\text { (II) }\end{array}$ & $\begin{array}{c}0.73 \pm 0.044 \\
\text { (II) }\end{array}$ & $33 \cdot 3$ & $\begin{array}{c}0.59 \pm 0.015 \\
(12)\end{array}$ & $\frac{0.69 \pm 0.019}{(12)}$ & 13.4 \\
\hline
\end{tabular}

Figures in parentheses are the numbers of observations. 


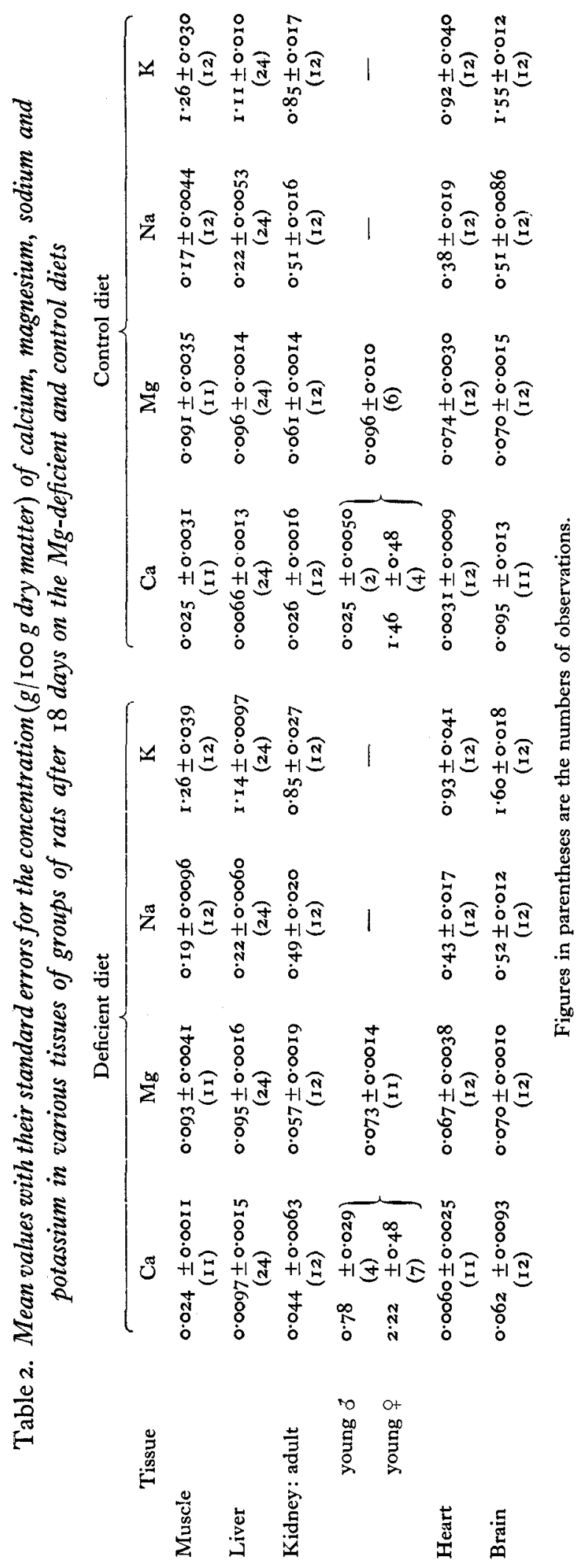


Soft tissues. The mean concentrations of $\mathrm{Mg}, \mathrm{Ca}, \mathrm{Na}$ and $\mathrm{K}$ in brain, heart, liver, kidney and muscle are shown in Table 2. There were no significant differences between the control and deficient groups of adult rats in the $\mathrm{Mg}$ content of any of the tissues examined. In the young rats, however, there was a significant $(P<0.01)$ reduction in the $\mathrm{Mg}$ content of the kidneys from rats fed on the $\mathrm{Mg}$-free diet. In addition, the $\mathrm{Mg}$ content of the kidneys from young rats on both diets was significantly $(P<0.01)$ higher than that of the kidneys from adult animals treated similarly.

The only detectable effect of $\mathrm{Mg}$ deficiency on the $\mathrm{Ca}$ content of soft tissues was in the kidney. Some of the kidneys from adult male rats showed increased Ca content whereas others remained normal. The range for $\mathrm{Ca}$ content was $0.024-0.10 \mathrm{Ig} / \mathrm{ro0} \mathrm{g}$ dry matter for the deficient animals and $0.020-0.038 \mathrm{~g} / \mathrm{ro0} \mathrm{g}$ dry matter for the controls. On the other hand, kidneys from the young male rats showed a consistent and much larger increase in Ca content, from a mean of 0.025 to one of $0.78 \mathrm{~g} / \mathrm{roog}$ dry matter in response to the $\mathrm{Mg}$-deficient diet. The $\mathrm{Ca}$ content of the kidneys of the young female rats was very variable; it ranged from 0.20 to $2.5 \%$ in the control group and from 0.73 to $4.1 \%$ in the deficient group.

Significant $(P<0.05)$ differences existed between the two groups of adult rats in the $\mathrm{Na}$ content of the heart and muscle, the deficient animals having a higher concentration in both tissues. The $\mathrm{K}$ content of the brains of the deficient animals was significantly $(P<0.05)$ higher than that of the control group.

\section{DISCUSSION}

The changes in plasma $\mathrm{Mg}$ resulting from feeding rats on a $\mathrm{Mg}$-free diet were found to be independent of the age of the rat. Despite the fact that the minimal values reached after a week on the diet were similar in both young and old rats the clinical signs of deficiency were more severe in the young animals. Young rats, for example, showed redness of the ears and increased excitability $2-3$ days earlier than the adults, and four of them were seen in convulsions. It will be noted that after a week on the Mg-free diet the concentration of $\mathrm{Mg}$ in the plasma was no longer a measure of the severity of $\mathrm{Mg}$ depletion.

Of the tissues examined, only bone showed a reduction in its $\mathrm{Mg}$ concentration, thus confirming the views of previous workers that the reserves of $\mathrm{Mg}$ in the body are confined mainly to the skeleton. The reduction in concentration of $\mathrm{Mg}$ in bones over a period of 3 weeks on the $\mathrm{Mg}$-free diet was much less in the adult than in the young rat. It was, in the femur for example, $28.2 \%$ in the young and $9.4 \%$ in the adult rat.

In order to calculate the total amount of $\mathrm{Mg}$ liberated from bone, the weight of the skeleton must also be known. Since more than $99 \%$ of the $\mathrm{Ca}$ in the body is confined to the skeleton its weight can be calculated from the concentrations of $\mathrm{Ca}$ in the body and in bone. From the extensive data for concentration of $\mathrm{Ca}$ in the body of rats of various weights given by Sherman \& MacLeod (1925) the amounts of $\mathrm{Ca}$ in the groups of rats at the beginning and end of the experimental period respectively were calculated to be $(\mathrm{g}) \mathrm{I} \cdot 3$ and $\mathrm{I} \cdot 7$ for the young females; $\mathrm{I} \cdot 7$ and $2 \cdot 2$ for the young males; $4 \cdot 2$ and 4.2 for the adult male rats. The concentration of $\mathrm{Ca}$ in the skeleton was taken to be 
$22 \%$, this value being the mean concentration of $\mathrm{Ca}$ in femur and mandible of both young and adult rats (Smith \& Field, unpublished). On the basis of the above values, and the concentration of $\mathrm{Mg}$ in the skeleton (taken as the mean for mandible and femur, Table I) the young females lost $4 \mathrm{mg}$, the young males $6 \mathrm{mg}$ and the adult male rats $13 \mathrm{mg} \mathrm{Mg}$. Thus it would appear that the lower availability of skeleton $\mathrm{Mg}$ in the adult rat is more than compensated for by the greater weight of skeleton. It was assumed that the rate of skeletal growth of the young rats on the $\mathrm{Mg}$-free diet was normal. If no skeletal growth took place during this period the amount of $\mathrm{Mg}$ liberated by the skeleton would be of the same order in both young and adult rats. To obtain the total reserves, the small amounts of $\mathrm{Mg}$ lost from the extracellular fluids must be taken into account. If it is assumed that the extracellular fluid accounts for $20 \%$ of the body-weight (Darrow \& Hellerstein, 1958), the amounts of $\mathrm{Mg}$ lost from this source were about 0.6 and $\mathrm{I} \cdot 2 \mathrm{mg}$ for the young and adult rats respectively.

The requirement for $\mathrm{Mg}$ of the adult rat is essentially that for maintenance, i.e. for making good the endogenous loss; any increase in weight is due to deposition of fat which contains negligible quantities of $\mathrm{Mg}$. The total endogenous loss over the 18 days cannot be determined exactly because of the carry-over of $\mathrm{Mg}$ from the previous stock diet. An approximation, however, may be calculated from the mean daily endogenous loss found for the last 9 days on the diet, when it was relatively constant at $0.78 \mathrm{mg} / \mathrm{rat}$ daily. This calculation gives a value of $14 \mathrm{mg}$, which is of the same order as that calculated above for the loss of $\mathrm{Mg}$ from the skeleton. No attempt was made to estimate the $\mathrm{Mg}$ requirements of the young rat, which are determined not only by maintenance but also by growth.

From the 2nd to the 9 th day the daily endogenous $\mathrm{Mg}$ excretion fell from $\mathrm{I} \cdot 17$ to $0.82 \mathrm{mg} / \mathrm{rat}$, and thereafter remained constant. This observation indicates that the maintenance requirement of the mature rat is reduced when there is a shortage of dietary $\mathrm{Mg}$, but this effect is strictly limited. The plasma $\mathrm{Mg}$, the source of endogenous $\mathrm{Mg}$ loss, showed the same pattern but the reduction was relatively greater (from 1.25 to $0.5 \mathrm{mg} / 100 \mathrm{ml}$ ). The value obtained for endogenous loss in the adult rat is equivalent to $2 \mathrm{mg} / \mathrm{kg}$ body-weight daily, which is of the same order as losses obtained for cows $(3.5 \mathrm{mg} / \mathrm{kg}$ (Blaxter \& McGill, 1956$), 1.5 \mathrm{mg} / \mathrm{kg}$ (Simesen, Lunaas, Rogers \& Luick, 1962)), for calves $\left(0.5^{-2} \cdot 2 \mathrm{mg} / \mathrm{kg}\right.$ (Smith, 1959)) and for sheep (2.0$3 \cdot 6 \mathrm{mg} / \mathrm{kg}$ (Field, McCallum \& Butler, I958), 2. I-5. I mg/kg (Care, I960)).

A striking feature of $\mathrm{Mg}$ deficiency in the young rat is a disturbance in $\mathrm{Ca}$ metabolism as evidenced by an increased $\mathrm{Ca}$ content of certain soft tissues and of kidney in particular (Watchorn \& McCance, 1937; Tufts \& Greenberg, 1937-8; MacIntyre \& Davidsson, 1958). The last workers reported a fourfold increase in $\mathrm{Ca}$ content of kidneys from female rats. On the other hand, Watchorn \& McCance (1937) using a mixture of males and females found a much greater but more variable increase, the $\mathrm{Ca}$ content of individual kidneys approaching $3 \%$ on a dry-matter basis.

Our results for kidney present a complicated picture. The Ca contents of the kidneys of the young female rats were similar to those reported by Watchorn \& McCance (1937) except that, although the Mg-deficient diet appeared to increase the $\mathrm{Ca}$ content, the difference was not significant owing to the large variation within both 
dietary groups. The values for the young male rats, on the other hand, were much less variable within each group and there was a thirtyfold difference between deficient and control animals. The effect of $\mathrm{Mg}$ deficiency was much less in adult than in young male rats, only one kidney showing a fourfold increase over the mean value for the controls.

No change in the $\mathrm{Mg}$ and $\mathrm{K}$ content of muscle has been found in the work described here, in contrast to the results of MacIntyre \& Davidsson (1958) who found a secondary depletion of $\mathrm{K}$ in muscle, which showed a highly significant positive correlation with the reduction of $\mathrm{Mg}$. However, these workers have given no values for the $\mathrm{K}$ content of muscle after 18 days on the diet but, since at this time they were unable to show any loss of $\mathrm{Mg}$, it follows that there was also no change in $\mathrm{K}$ concentration. Thus the differences between their results and ours can be attributed to the shorter duration of our experiment.

There was an increase in the muscle $\mathrm{Na}$ of the deficient adult rats in agreement with the results of MacIntyre \& Davidsson (1958) for young rats. In addition we found an increase in the $\mathrm{Na}$ content of hearts from the deficient animals. In contrast to MacIntyre \& Davidsson (1958), we found an increased $\mathrm{K}$ content in the brain of Mgdeficient rats.

\section{SUMMARY}

I. Young and adult rats were given for 18 days a semi-synthetic diet free of magnesium, or the same diet supplemented with $\mathrm{Mg}$. Plasma $\mathrm{Mg}$ levels were determined at intervals during the experimental period, after which the animals were killed and $\mathrm{Mg}$ was determined in plasma and selected tissues. The content of sodium, potassium and calcium in soft tissues and the endogenous losses of $\mathrm{Mg}$ were measured in adult rats.

2. Vasodilation of the ears and hyperirritability took 2-3 days longer to appear in adult than in young rats on the $\mathrm{Mg}$-free diet. Convulsions were seen only in young rats.

3. The concentration of $\mathrm{Mg}$ in plasma and the endogenous loss of $\mathrm{Mg}$ of adult rats given the $\mathrm{Mg}$-free diet fell during the first 8 days and thereafter remained constant at $0.5 \mathrm{mg} / \mathrm{I} 00 \mathrm{ml}$ and $0.8 \mathrm{mg} / \mathrm{rat}$ day respectively. Changes in plasma $\mathrm{Mg}$ of young rats were similar.

4. After I8 days the mean concentration of $\mathrm{Mg}$ in the femur and mandible of the deficient group had decreased by 9.5 and $13.4 \%$ respectively in adults and 28.2 and $33.3 \%$ respectively in young rats.

5. No changes in the $\mathrm{Mg}$ mean concentrations of the brain, heart, liver, kidneys and muscle were detected in the deficient adult group. The kidneys of the young rats showed a reduction in $\mathrm{Mg}$ content in the deficient group.

6. The concentrations of $\mathrm{Na}$ in heart and muscle and of $\mathrm{K}$ in brain were significantly higher in the deficient adult group than in the controls.

7. An increased concentration of $\mathrm{Ca}$ in the kidney due to $\mathrm{Mg}$ deficiency occurred in young males but not in young females or in adult males.

8. The differences in the effects of the $\mathrm{Mg}$-free diet on mature and young rats are discussed. 
We thank Mrs N. M. Fisher and Messrs A. J. Minto and A. G. Brown for skilled technical assistance. We are grateful to Roche Products Ltd and Cyanamid of Great Britain Ltd for gifts of Synkavit and chlortetracycline hydrochloride respectively.

\section{REFERENCES}

Blaxter, K. L. \& McGill, R. F. (1956). Vet. Rev. Annot. 2, 35.

Blaxter, K. L., Rook, J. A. F. \& MacDonald, A. M. (1954). F. comp. Path. 64, I 57.

Burhoe, S. O. (1940). F. Hered. 31, 445.

Care, A. D. (1960). Res. vet. Sci. 1, 338 .

Cuthbertson, W. F. J. (1957). Proc. Nutr. Soc. 16, 70.

Darrow, D. C. \& Hellerstein, S. (1958). Physiol. Rev. 38, 114.

Duckworth, J., Godden, W. \& Warnock, G. M. (1940). Biochem. F. 34, 97.

Field, A. C., McCallum, J. W. \& Butler, E. J. (1958). Brit. F. Nutr. 12, 433.

Field, A. C. \& Smith, B. S. W. (1964). Brit. $\mathcal{~}$. Nutr. 18. (In the Press).

Henley, A. A. \& Saunders, R. A. (1958). Analyst, 83, 584.

L'Estrange, J. L. \& Axford, R. F. E. (1963). Proc. Nutr. Soc. 22, i.

MacIntyre, I. \& Davidsson, D. (1958). Biochem. F. 70, 456.

Rook, J. A. F. \& Balch, C. C. (1958). J. agric. Sci. 51, 199.

Sherman, H. C. \& MacLeod, F. L. (1925). F. biol. Chem. 64, 429.

Simesen, M. G., Lunaas, T., Rogers, T. A. \& Luick, J. R. (1062). Acta vet. scand. 3, 75.

Smith, R. H. (1959). Biochem. J. 7r, 306.

Tufts, E. V. \& Greenberg, D. M. (1937-8). F. biol. Chem. 122, 693.

Watchorn, E. \& McCance, R. A. (1937). Biochem. F. 31, 1379.

Wilson, A. A. (1960). Vet. Rev. Annot. 6, 39. 